\title{
Article \\ Population with Long-Term Care Needs in Six Latin American Countries: Estimation of Older Adults Who Need Help Performing ADLs
}

\author{
Mauricio Matus-Lopez *(D) and Alexander Chaverri-Carvajal (D) \\ Department of Economics, Quantitative Methods and Economic History, Universidad Pablo de Olavide, \\ 41013 Seville, Spain; achacar@alu.upo.es \\ * Correspondence: mmatlop@upo.es
}

check for

updates

Citation: Matus-Lopez, M.; Chaverri-Carvajal, A. Population with Long-Term Care Needs in Six Latin American Countries:

Estimation of Older Adults Who Need Help Performing ADLs. Int. J Environ. Res. Public Health 2021, 18 7935. https://doi.org/10.3390/ ijerph18157935

Academic Editors: Aurea Grané and Irene Albarrán

Received: 14 June 2021

Accepted: 23 July 2021

Published: 27 July 2021

Publisher's Note: MDPI stays neutral with regard to jurisdictional claims in published maps and institutional affiliations.

Copyright: (c) 2021 by the authors. Licensee MDPI, Basel, Switzerland. This article is an open access article distributed under the terms and conditions of the Creative Commons Attribution (CC BY) license (https:// creativecommons.org/licenses/by/ $4.0 /)$

\begin{abstract}
The population in Latin America is ageing, and there is an inevitable demand for long-term care services. However, there are no comparative analyses between Latin American countries of the dependency situation of older adults. This study aims to calculate and compare percentages of older adults who need help performing the activities of daily living in six Latin American nations. The study is observational, transversal, and cross-national and uses microdata drawn from national surveys conducted in Argentina $(n=3291)$, Brazil $(n=3903)$, Chile $(n=31,667)$, Colombia $(n=$ $17,134)$, Mexico $(n=7909)$, and Uruguay $(n=4042)$. Comparable indicators of the need for help in performing the basic and instrumental activities of daily living were calculated. The percentages of older adults in need of help for basic activities of daily living ranged from $5.8 \%$ in Argentina to $11 \%$ in Brazil; for instrumental activities of daily living, from $13.8 \%$ in Mexico to $35.7 \%$ in Brazil; and combined, from $18.1 \%$ in Argentina to $37.1 \%$ in Brazil. Brazil thus has the highest indicators, followed by Colombia. The results warn of the frail physical condition of older people and the high potential demand for long-term care services. The information provided could be useful for further research on and planning for long-term care needs in Latin American and middle-income countries.
\end{abstract}

Keywords: long-term care; activities of daily living; frail elderly; Latin America; Uruguay; Chile; Argentina; Brazil; Colombia; Mexico

\section{Introduction}

One of the current main challenges for Latin American governments is to respond to the demands associated with the rapid and unprecedented ageing of the populationwithin the next 25 years, there will be more older adults (65 years and over) than children (under 15 years) [1]. This demographic change will require resources and reforms of social security systems [2], and both the World Health Organization and the Economic Commission for Latin America and the Caribbean have called on governments to develop long-term care (LTC) systems for older adults [3,4].

LTC encompasses the broad range of services and assistance provided to people who are limited in their ability to function independently on a daily basis, i.e., people who, for an extended period, need help to carry out activities of daily living (ADL), such as eating, showering, or getting dressed [5,6]. These services are classified as either home-based or residential; the former include services that allow the beneficiary to continue living in their own home (home care assistance, day and night care centers, telecare, etc.), while the latter are services provided in facilities, such as nursing homes, where the beneficiary has access to care and functional support $24 \mathrm{~h}$ a day-these are designed for the most severe health situations [7]. Internationally, the term most widely used to refer to these two types of services is 'long-term care', but in Spanish-speaking countries, the term 'dependencia' (dependency) is most often employed. The majority of LTC recipients are older adults: four out of five are over 65 years old [6]. 
During the 20th century, around 30 high-income countries, including Netherlands, Japan, and Spain, created their own LTC systems; in Latin America, Uruguay did so in 2015 and Costa Rica approved such a system in 2021 [8,9]. Many lessons can be learned from the experiences in other countries, one of which being that the first step in designing an LTC system is to know the number of people who will need it in the future $[3,10]$. Thus, the usual performance of basic and instrumental ADLs in a country's physical and cultural context should be evaluated, together with other variables, such as the frequency and intensity of the help required by older people [11-13]. Each country can then determine the specific eligibility criteria for access to the services provided by their LTC systems [14-18].

Among Latin American countries, nationally representative estimates of the older population with LTC needs have been made in Uruguay, Chile, Argentina, Mexico, and Costa Rica. There are also studies based on less representative samples, such as in cities or administrative regions [19-23]. These estimates provide a wide range of results that vary in terms of the age threshold used for older adults (60 or 65 years old) and the estimation methodology [24-28]. With only one exception, these studies are not comparable between countries [29], and there are no nationally representative multi-country studies, so it is not possible to know the situation in one country with respect to the others.

This study aims to calculate and compare percentages of older adults who need help with ADLs in six Latin American countries. The methodology is based on the experiences of similar research in other countries, and the sources are national surveys conducted in Argentina, Brazil, Chile, Colombia, Mexico, and Uruguay, from which microdata have been drawn. The results are presented both raw and standardized according to population structure; they are thus comparable between countries.

\section{Materials and Methods}

\subsection{Sources}

The selection of countries was limited to Latin America and based on these two criteria: (a) the existence of a national survey on health, ageing or living conditions in which older adults aged 65 and over were represented and (b) the availability of the survey through public access or upon request to the institution that conducted it.

Six Latin American countries were included: Argentina, Brazil, Chile, Colombia, Mexico, and Uruguay. These countries account for $70 \%$ of the population of the region. Despite similarities, the countries do differ; the highest per capita income of Chile and Uruguay, the largest population size of Brazil and Mexico, and the smallest population size of Uruguay can be highlighted. However, within the region, these are the countries that will have the largest older adult populations in the years to come (Table 1).

Table 1. Main indicators for countries selected; 2020 or latest year available.

\begin{tabular}{|c|c|c|c|c|c|c|}
\hline \multirow{2}{*}{ Country } & \multirow{2}{*}{$\begin{array}{l}\text { Population } \\
\text { (Million) }\end{array}$} & \multicolumn{2}{|c|}{$\% 65$ and Older } & \multirow{2}{*}{$\begin{array}{c}\text { GDP } \\
\text { Per Capita }\end{array}$} & \multirow{2}{*}{$\begin{array}{l}\text { Country Group } \\
\text { by Income }\end{array}$} & \multirow{2}{*}{$\begin{array}{c}\text { Life } \\
\text { Expectancy }\end{array}$} \\
\hline & & 2020 & 2050 & & & \\
\hline Argentina & 45.61 & 9.5 & 15.1 & 9890.31 & Upper-middle income & 76.6 \\
\hline Brazil & 213.99 & 8.4 & 20.5 & 8932.39 & Upper-middle income & 75.9 \\
\hline Chile & 19.21 & 10.7 & 23.4 & $14,615.95$ & High-income & 80.7 \\
\hline Colombia & 51.27 & 8.2 & 19.1 & 6419.48 & Upper-middle income & 79.3 \\
\hline Mexico & 130.26 & 7.0 & 15.0 & $10,024.42$ & Upper-middle income & 76.0 \\
\hline Uruguay & 3.49 & 12.2 & 19.0 & $17,681.21$ & High-income & 77.0 \\
\hline
\end{tabular}

National surveys on health, ageing, and living conditions were used as sources for this observational and transversal study. There were four survey selection criteria: (a) examining ageing, health, or living conditions; (b) including a nationally representative sample of older adults; (c) analyzing variables related to ADLs; and (d) being the latest version released. In all the surveys, older adults were defined as people aged 65 and over. The description of the sources and the size of the sample $(\mathrm{N})$ are shown in Table 2. 
Table 2. Description of the sources, country, name, year, coverage, and sample of adults 65 and older (Obs. and \% sample) ${ }^{+}$.

\begin{tabular}{|c|c|c|c|}
\hline Country & Survey (Acronym and Year) & $\begin{array}{l}\text { Coverage } \\
\text { (by Age) }\end{array}$ & $\begin{array}{c}65+ \\
\text { Observations (\%) }\end{array}$ \\
\hline Argentina & $\begin{array}{c}\text { Encuesta Nacional sobre Calidad de Vida de Adultos } \\
\text { Mayores (ENCAVIAM, 2012) }\end{array}$ & 60 years and older & $3291(70.8 \%)$ \\
\hline Brazil & $\begin{array}{l}\text { Estudo Longitudinal da Saúde dos Idosos } \\
\text { (ELSI, 2015/16) }\end{array}$ & 50 years and older & $3903(41.5 \%)$ \\
\hline Chile & $\begin{array}{l}\text { Encuesta de Caracterización Socioeconómica Nacional } \\
\qquad(\text { CASEN, 2017) }\end{array}$ & All ages & $31,667(14.6 \%)$ \\
\hline Colombia & $\begin{array}{l}\text { Encuesta Nacional de Salud, Envejecimiento y Vejez } \\
\text { (SABE, 2015) }\end{array}$ & 60 years and older & $17,134(72.3 \%)$ \\
\hline Mexico & $\begin{array}{l}\text { Encuesta Nacional sobre Salud y Envejecimiento } \\
\text { (ENASEM, 2018) }\end{array}$ & 50 years and older & $7909(48.8 \%)$ \\
\hline Uruguay & $\begin{array}{c}\text { Encuesta Longitudinal de Protección Social } \\
\text { (ELPS, 2015/16) }\end{array}$ & 16 years and older & $4042(34.1 \%)$ \\
\hline
\end{tabular}

+ Sampling method: ENCAVIAM: probabilistic, random, clustered, multi-stage. ELSI: stratified, random, multi-stage. CASEN: random, geographic stratification, multi-stage. SABE: probabilistic, clustered, stratified, multi-stage. ENASEM: probabilistic, random, clustered. ELPS: random, stratified by clusters, multi-stage. See links to methodological documents in Appendix A.

\subsection{Variables}

\subsubsection{Activities of Daily Living}

Three groups of ADLs were used. The first group (basic ADLs, BADL) included basic activities taken from the Katz index [30]. Due to limitations of the surveys, the BADL group in the current study comprised only four such activities in each of the six countries: dressing, toileting, transferring, and feeding (Table 3, X: available in the survey; n.a: not available in the survey).

Table 3. Activities of the Katz Index and activities of the Lawton scale included in the study, by country/survey.

\begin{tabular}{|c|c|c|c|c|c|c|c|c|}
\hline $\begin{array}{l}\text { Index/ } \\
\text { Scale }\end{array}$ & Activities & $\begin{array}{c}\text { Argentina } \\
\text { ENCAVIAM }\end{array}$ & $\begin{array}{l}\text { Brazil } \\
\text { ELSI }\end{array}$ & $\begin{array}{l}\text { Chile } \\
\text { CASEN }\end{array}$ & $\begin{array}{l}\text { Colombia } \\
\text { SABE }\end{array}$ & $\begin{array}{c}\text { Mexico } \\
\text { ENASEM }\end{array}$ & $\begin{array}{l}\text { Uruguay } \\
\text { ELPS }\end{array}$ & $\begin{array}{c}\text { Activities } \\
\text { Selected }\end{array}$ \\
\hline \multirow{6}{*}{ Katz Index } & Bathing & $x$ & $x$ & $X$ & $x$ & $X$ & n.a & No \\
\hline & Continence & n.a & $X$ & n.a & $x$ & n.a & n.a & No \\
\hline & Dressing & $X$ & $x$ & $X$ & $x$ & $X$ & $x$ & Yes \\
\hline & Feeding & $x$ & $x$ & $x$ & $x$ & $x$ & $x$ & Yes \\
\hline & Toileting & $x$ & $x$ & $x$ & $x$ & $x$ & $x$ & Yes \\
\hline & Transferring & $x$ & $x$ & $x$ & $x$ & $x$ & $x$ & Yes \\
\hline \multirow{7}{*}{$\begin{array}{l}\text { Lawton } \\
\text { Scale }\end{array}$} & $\begin{array}{l}\text { Using } \\
\text { telephone }\end{array}$ & $x$ & $x$ & $x$ & $x$ & n.a & n.a & No \\
\hline & Shopping & $x$ & $x$ & $x$ & $x$ & $x$ & n.a & Yes \\
\hline & $\begin{array}{l}\text { Food prepa- } \\
\text { ration }\end{array}$ & $x$ & $x$ & n.a & $x$ & $x$ & n.a & Yes \\
\hline & Housekeeping & $x$ & $x$ & $X$ & n.a & n.a & $x$ & No \\
\hline & Transportation & $x$ & $x$ & n.a & $X$ & n.a & n.a & No \\
\hline & Medication & $x$ & $x$ & n.a & $x$ & $X$ & n.a & Yes \\
\hline & $\begin{array}{c}\text { Handling } \\
\text { finances }\end{array}$ & $x$ & $x$ & n.a & $x$ & $x$ & n.a & Yes \\
\hline
\end{tabular}

The second group (instrumental ADLs, IADL) was based on the instrumental activities of the Lawton scale [31]. Again, the group in the current study included only some of those activities because not all were assessed in the surveys. The IADL group comprised four instrumental activities - shopping, food preparation, medication, and handling of finances (Table 2)-but only in four countries because the surveys conducted in Chile and Uruguay did not provide this information.

Finally, we considered the ADL group as aggregation of the first and second groups: eight ADLs in total (four basic and four instrumental). 


\subsubsection{Need for Help}

The questionnaires of the six surveys included questions that assessed whether older adults needed help to perform ADLs, but the available responses varied. Argentina and Mexico used a binary option (yes/no), Brazil used three categories (does not need; needs but does not receive; needs and receives), Chile and Uruguay used scales to measure the frequency of need (never; almost never; sometimes; often; always) and Colombia used a combination of need for help and difficulty (no help and no difficulty; no help but difficulty; needs help; unable to do it). In the current study, the answers were coded as a binary variable called 'help', as shown in Table 4.

Table 4. Reclassification of original variables into a new variable ('help') ${ }^{+}$.

\begin{tabular}{ccc}
\hline Variable Help/Country & Yes & No \\
\hline Argentina (ENCAVIAM) & Yes & No \\
Brazil (ELSI) & Need but don't get; Need and get & Don't need \\
Chile (CASEN) & Almost never; Sometimes; Many times; Always & Never \\
Colombia (SABE) & Needs help; Can't do it & No help and no difficulty; No help but difficulty \\
Mexico (ENASEM) & No & Never \\
Uruguay (ELPS) & Almost never; Sometimes; Many times; Always & \\
\hline
\end{tabular}

+ Using conservative criteria, we categorized the missing values as 'no help required' (No). The missing values were $0.2 \%$ or less in Brazil, Chile, and Colombia, $0 \%$ in Argentina and Uruguay, and $0.5 \%$ or less in Mexico.

The information regarding the activities and questions considered is available in the original language in Appendix A.

\subsection{Indexes}

Three indexes were calculated. The first (BADL index) measures the percentage of older adults who require help from another person to perform at least one of the four activities in the BADL group; the second (IADL index) measures the percentage who need help performing at least one of the four activities in the IADL group; and the third (ADL index) measures the percentage who need help with any of the eight activities.

The indexes were calculated as follows:

$$
\text { Index }=\frac{\sum P_{(x=1)}}{\sum\left[P_{(x=1)}+P_{(x=0)}\right]}
$$

where $P$ is the older adult population of the sample and $x=1$ if they need help for any activity or $x=0$ otherwise. The range of the index value is [0,1]. The formula is valid for the three indexes when help is considered for BADLs, IADLs, or both, as appropriate.

\subsection{Standardization}

There are two reasons that may explain a country's index (ADL or BADL) being higher than that of another country. First, the worse physical condition or health of its population. Second, a larger population who are either in the oldest age group (older adults are more dependent) or female (women are more dependent). Standardization consists of separating these effects. For this purpose, the same structure of population was applied to each country and the rates were weighted by age groups. Below is an example of the process for two countries and two age groups (Table 5). 
Table 5. Standardization example (for two countries).

\begin{tabular}{|c|c|c|c|c|c|}
\hline \multirow{2}{*}{$\begin{array}{l}\text { Percentage of Older Adult } \\
\text { Population by Age }\end{array}$} & \multicolumn{2}{|c|}{ Population (\%) } & \multicolumn{2}{|c|}{ Index (Value) } & \multirow{2}{*}{ Standard Structure } \\
\hline & Country X & Country $Y$ & Country $X$ & Country $Y$ & \\
\hline 65-80 & $60 \%$ & $80 \%$ & 0.15 & 0.15 & $70 \%$ \\
\hline 80 and more & $40 \%$ & $20 \%$ & 0.30 & 0.40 & $30 \%$ \\
\hline Total, non-standardized & $100 \%$ & $100 \%$ & 0.21 & 0.20 & $100 \%$ \\
\hline Total, standardized & & & 0.195 & 0.225 & \\
\hline
\end{tabular}

Country $\mathrm{X}$ has a higher index $(0.21)$ than country $\mathrm{Y}(0.20)$ because the population aged 80 years and over is larger in country $X(40 \%)$ than country $Y(20 \%)$. If the countries had the same age structure (standard structure), the index of country $X(0.195=0.15 \times 70 \%+0.3 \times 30 \%)$ would be lower than the index of country Y $(0.225=0.15 \times 70 \%+0.4 \times 30 \%)$.

The results are expressed in gross and standardized percentages. Standardization was performed based on the population structure of Latin America and the Caribbean, disaggregated by sex and age. The gross percentage shows the percentage of dependents, given the population structure of older adults of each country, by sex and age. The standardized percentage shows the same percentage if all countries had the same population structure.

\subsection{Complementary Analyses}

Three complementary analyses were performed. First, the saturation of responses was analyzed through the weighting of the three most frequent activities. We calculated the percentage of the index (BADL and IADL index) that would have been captured if only three activities had been considered. The higher the percentage, the lower the contribution of evaluating a fourth activity. Below is an example of the saturation of the BADL index for one country (Table 6).

Table 6. Saturation analysis example.

\begin{tabular}{cccccc}
\hline \multirow{2}{*}{ Need Help with ... } & \multicolumn{2}{c}{ Answer } & & \multicolumn{2}{c}{ Index } \\
\cline { 2 - 6 } & Yes & No & Value & Increase & Saturation \\
\hline Only dressing & $4.5 \%$ & $95.5 \%$ & 0.045 & 0.05 & $43 \%$ \\
Dressing and transferring & $7.5 \%$ & $92.5 \%$ & 0.075 & 0.03 & $71 \%$ \\
Dressing, transferring and toileting & $9.5 \%$ & $90.5 \%$ & 0.095 & 0.02 & $90 \%$ \\
Dressing, ... and feeding & $10.5 \%$ & $89.5 \%$ & 0.105 & 0.01 & $100 \%$ \\
Total & $10.5 \%$ & $89.5 \%$ & 0.105 & & \\
\hline
\end{tabular}

The value of the index is 0.11 . The contribution of each activity to the index is decreasing and is listed in descending order (column increment). Saturation measures the sum of the three first activities $(90 \%=0.095 \div 0.105 \times 100)$. The higher the value, the less relevant the inclusion of a new activity and the more consistent the index.

The second analysis focused on association. Non-parametric Tau-b Kendall tests were performed for each country and activity. The higher the coefficient, the greater the association between the activities, for a given level of significance.

Finally, severity was calculated as the number of activities for which help was needed. The higher the value, the greater the percentage of people who require help in that number of activities.

\section{Results}

\subsection{Need for Help}

Figure 1 shows the percentages by country of older adults who need help with BADLs and IADLs. The percentages are presented both standardized according to sex and age structure and non-standardized. 


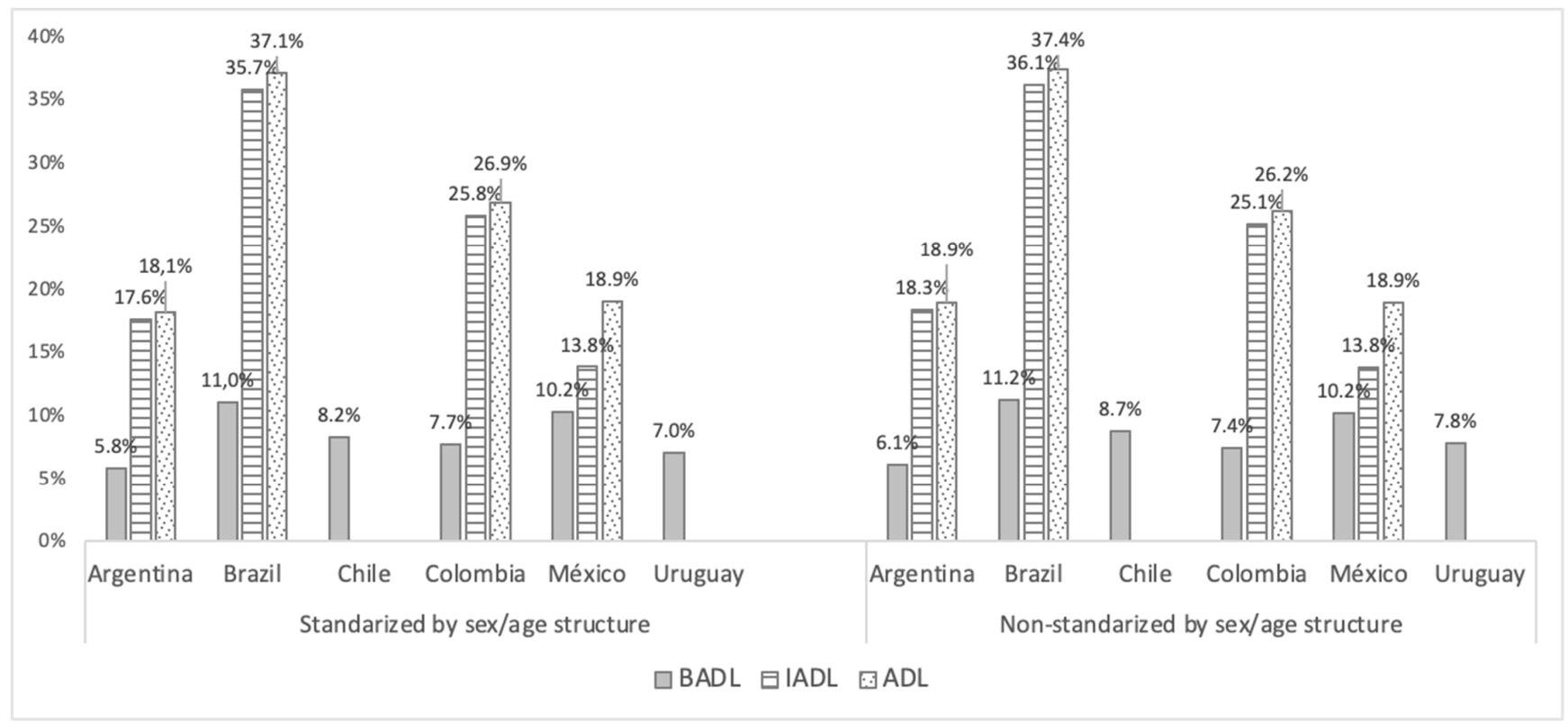

Figure 1. Percentages of older adults (65+) who needs help to perform BADLs, IADLs, or any of both (ADL) by country (standardized and non-standardized).

The BADL index ranges from 5.8\% to $11 \%$. Argentina and Uruguay are the lowest, Colombia and Chile have intermediate values, and Mexico and Brazil both exceed 10\%.

The range for the IADL index is wider, from $13.8 \%$ to $36.1 \%$. Compared to the BADL results, the IADL index rates for Colombia are highest. In absolute terms, the rates for Brazil are the highest, followed by Colombia, with values close to $25 \%$, then Argentina and Mexico. The consideration of all activities in the ADL index increased the rates for all countries, especially Mexico, which thus reaches the level of Argentina. Table 7 shows the results by sex and age.

Table 7. Percentages of older adults (65+) who needs help to perform any BADLs, IADLs, or both (ADLs) by sex, age, and country.

\begin{tabular}{|c|c|c|c|c|c|c|c|c|c|c|c|c|c|}
\hline \multirow{2}{*}{ Index } & \multirow{2}{*}{ Age } & \multicolumn{2}{|c|}{ Argentina } & \multicolumn{2}{|c|}{ Brazil } & \multicolumn{2}{|c|}{ Chile } & \multicolumn{2}{|c|}{ Colombia } & \multicolumn{2}{|c|}{ Mexico } & \multicolumn{2}{|c|}{ Uruguay } \\
\hline & & Men & Women & Men & Women & Men & Women & Men & Women & Men & Women & Men & Women \\
\hline \multirow{5}{*}{$\begin{array}{l}\text { BADL } \\
\text { index }\end{array}$} & $65-69$ & $3.1 \%$ & $2.1 \%$ & $4.9 \%$ & $5.9 \%$ & $3.5 \%$ & $3.2 \%$ & $2.4 \%$ & $2.6 \%$ & $2.9 \%$ & $5.0 \%$ & $3.0 \%$ & $5.0 \%$ \\
\hline & $70-74$ & $5.3 \%$ & $2.9 \%$ & $6.1 \%$ & $11.2 \%$ & $4.6 \%$ & $4.8 \%$ & $3.7 \%$ & $2.8 \%$ & $4.8 \%$ & $8.4 \%$ & $4.0 \%$ & $5.8 \%$ \\
\hline & $75-79$ & $4.5 \%$ & $4.5 \%$ & $8.0 \%$ & $14.7 \%$ & $6.5 \%$ & $9.2 \%$ & $7.9 \%$ & $7.8 \%$ & $7.2 \%$ & $13.2 \%$ & $6.2 \%$ & $9.4 \%$ \\
\hline & $80+$ & $11.4 \%$ & $16.6 \%$ & $19.1 \%$ & $24.1 \%$ & $17.2 \%$ & $23.4 \%$ & $15.9 \%$ & $25.8 \%$ & $17.7 \%$ & $29.0 \%$ & $10.3 \%$ & $15.8 \%$ \\
\hline & Total & $5.6 \%$ & $6.5 \%$ & $8.6 \%$ & $12.8 \%$ & $7.1 \%$ & $9.9 \%$ & $6.2 \%$ & $8.4 \%$ & $7.5 \%$ & $12.4 \%$ & $5.5 \%$ & $9.4 \%$ \\
\hline \multirow{5}{*}{$\begin{array}{l}\text { IADL } \\
\text { index }\end{array}$} & $65-69$ & $7.2 \%$ & $9.9 \%$ & $23.2 \%$ & $26.4 \%$ & - & - & $13.4 \%$ & $8.4 \%$ & $4.3 \%$ & $7.8 \%$ & - & - \\
\hline & $70-74$ & $11.3 \%$ & $13.4 \%$ & $25.0 \%$ & $32.7 \%$ & - & - & $19.6 \%$ & $16.3 \%$ & $5.5 \%$ & $13.4 \%$ & - & - \\
\hline & $75-79$ & $16.6 \%$ & $27.1 \%$ & $38.0 \%$ & $42.6 \%$ & - & - & $34.8 \%$ & $26.9 \%$ & $11.0 \%$ & $18.8 \%$ & - & - \\
\hline & $80+$ & $22.7 \%$ & $42.2 \%$ & $50.5 \%$ & $62.5 \%$ & - & - & $56.7 \%$ & $57.4 \%$ & $23.3 \%$ & $34.5 \%$ & - & - \\
\hline & Total & $13.1 \%$ & $22.1 \%$ & $32.1 \%$ & $38.7 \%$ & - & - & $26.6 \%$ & $23.9 \%$ & $10.1 \%$ & $16.9 \%$ & - & - \\
\hline \multirow{5}{*}{$\begin{array}{l}\text { ADL } \\
\text { index }\end{array}$} & $65-69$ & $7.4 \%$ & $9.9 \%$ & $24.2 \%$ & $28.2 \%$ & - & - & $14.4 \%$ & $9.7 \%$ & $6.2 \%$ & $10.6 \%$ & - & - \\
\hline & $70-74$ & $11.4 \%$ & $15.4 \%$ & $26.3 \%$ & $33.7 \%$ & - & - & $21.3 \%$ & $17.2 \%$ & $9.0 \%$ & $17.2 \%$ & - & - \\
\hline & $75-79$ & $17.6 \%$ & $27.2 \%$ & $38.3 \%$ & $44.4 \%$ & - & - & $35.4 \%$ & $28.2 \%$ & $14.0 \%$ & $23.7 \%$ & - & - \\
\hline & $80+$ & $24.2 \%$ & $42.5 \%$ & $52.5 \%$ & $63.7 \%$ & - & - & $57.6 \%$ & $58.3 \%$ & $32.5 \%$ & $49.0 \%$ & - & - \\
\hline & Total & $13.7 \%$ & $22.7 \%$ & $33.2 \%$ & $40.1 \%$ & - & - & $27.7 \%$ & $25.1 \%$ & $14.3 \%$ & $22.8 \%$ & - & - \\
\hline
\end{tabular}

BADL: Basic activities of daily living; IADLs: Instrumental activities of daily living; ADL: Activities of daily living.

The indexes confirm international trends in terms of age and sex. For instance, in the BADL index, the values increase with age; for women in the first age group (65-69 years), the values range between 2.1\% for Argentina and 5.9\% for Brazil, but for the older age group (80 years and over), Uruguay has the lowest percentage (15.8\%) and Mexico the highest (29\%). Among men, this age-related increase is not so evident, with values ranging from $2.4 \%$ for Colombia to $4.9 \%$ for Brazil in the lower age group and from $10.3 \%$ for Uruguay to $19.1 \%$ for Brazil in the higher age group. 
In almost all age groups of age in the three indexes, women need more help than men, but there are exceptions, such as women and men aged 65-69 in Argentina and Chile, according to the BADL index. Nevertheless, in the 80-and-over age group, there is no inconsistency in the pattern of the indexes and countries: women always need more help than men. In these countries, the most notable exception to the pattern of gender and need for help is Colombia, where men have the highest total values for both the IADL and ADL indexes.

\subsection{Complementary Analysis}

The correlation between activities is high. All tests yielded significant and positive results, with stronger relationships among BADLs than IADLs (Table 8).

Table 8. Complementary analysis.

\begin{tabular}{|c|c|c|c|c|c|c|}
\hline Test/Indicator & Argentina & Brazil & Chile & Colombia & México & Uruguay \\
\hline \multicolumn{7}{|l|}{ Correlation (Tau-b) } \\
\hline Feeding \&Toileting & $0.534^{* *}$ & $0.519 * *$ & $0.642^{* *}$ & $0.460 * *$ & $0.537^{* *}$ & $0.505^{* *}$ \\
\hline Feeding \& Transferring & $0.552 * *$ & $0.493 * *$ & $0.603 * *$ & $0.398 * *$ & $0.551^{* *}$ & $0.427 * *$ \\
\hline Feeding \& Dressing & $0.550 * *$ & $0.397^{* *}$ & $0.575^{* *}$ & $0.473^{* *}$ & $0.230 * *$ & $0.486^{* *}$ \\
\hline Toileting \& Transferring & $0.695^{* *}$ & $0.678^{* *}$ & $0.808^{* *}$ & $0.694^{* *}$ & $0.709^{* *}$ & $0.599 * *$ \\
\hline Toileting \& Dressing & $0.632 * *$ & $0.554^{* *}$ & $0.770 * *$ & $0.641^{* *}$ & $0.331^{* *}$ & $0.701^{* *}$ \\
\hline Transferring \& Dressing & $0.702 * *$ & $0.544^{* *}$ & $0.806^{* *}$ & $0.576^{* *}$ & $0.365^{* *}$ & $0.607^{* *}$ \\
\hline Shopping \& Food Preparation & 0.624 ** & $0.451^{* *}$ & - & $0.582 * *$ & $0.587^{* *}$ & - \\
\hline Shopping \& Medication & $0.482 * *$ & $0.376^{* *}$ & - & $0.547^{* *}$ & $0.374^{* *}$ & - \\
\hline Shopping \& Handle Finances & $0.452 * *$ & $0.487^{* *}$ & - & $0.605^{* *}$ & $0.376^{* *}$ & - \\
\hline Food Preparation \& Medication & 0.530 ** & $0.372 * *$ & - & $0.518 * *$ & $0.414^{* *}$ & - \\
\hline Food Preparation \& Handle Finances & $0.485 * *$ & $0.436^{* *}$ & - & $0.462 * *$ & $0.413^{* *}$ & - \\
\hline Medication \& Handle Finances & $0.631^{* *}$ & $0.387^{* *}$ & - & $0.532 * *$ & $0.499 * *$ & - \\
\hline \multicolumn{7}{|c|}{ Saturation analysis (\% cumulative activities) } \\
\hline 3 BADL over BADL Index & $96.4 \%$ & $97.5 \%$ & $97.4 \%$ & $93.8 \%$ & $94.3 \%$ & $91.3 \%$ \\
\hline 3 IADL over IADL Index & $96.4 \%$ & $92.6 \%$ & - & $97.5 \%$ & $96.6 \%$ & - \\
\hline \multicolumn{7}{|c|}{ Distribution by number of ADL help (\%) } \\
\hline Only 1 ADL & $43.6 \%$ & $46.4 \%$ & $27.0 \%$ & $44.8 \%$ & $39.7 \%$ & $41.0 \%$ \\
\hline $2-4$ ADL & $37.9 \%$ & $40.4 \%$ & $73.0 \%$ & $39.8 \%$ & $49.8 \%$ & $59.0 \%$ \\
\hline $5-6 \mathrm{ADL}$ & $10.7 \%$ & $7.4 \%$ & - & $7.6 \%$ & $5.7 \%$ & - \\
\hline 7-8 ADL & $7.8 \%$ & $5.7 \%$ & - & $7.8 \%$ & $4.9 \%$ & - \\
\hline
\end{tabular}

**: Significant at the 0.05 level.

The saturation of three activities is particularly high; the three BADLs most frequently mentioned in the surveys were dressing, transferring, and walking, accounting for between $91 \%$ and $97 \%$ of all answers concerning BADLs. For IADLs, the three most frequently mentioned were shopping, food preparation and medication, which accounted for $92 \%$ to $97 \%$ of all answers.

The distribution of ADLs shows that approximately two out of every five people who gave positive answers need help for only one ADL, except in Chile, where the percentage is lower. A positive answer means that the person responded that they do need help (see Table 4). In contrast, more than $7 \%$ of the population in Argentina and Colombia responded that they require help with seven or more ADLs.

\section{Discussion}

The main objective of this study was to calculate and compare the percentages of older adults who need help in performing ADLs in six Latin American countries. The tools and definitions for calculating the need for help among older people vary between countries [32], but in both applied and research measures, indexes that comprise both BADLs and IADLs are often used [33-35], and most measures include the activities considered in the indexes of the current study [36]. Once a person starts needing help, the need often 
increases over time [37] and measuring the size of the population in need of such help allows the services provided by LTC systems—and their costs—-to be planned [38].

In this study, we calculated and compared, for the first time, the proportions of older people who need help to perform ADLs in six Latin American countries. Comparisons between the results of this work and previous studies are not direct-as previously noted, measurement methodologies differ, making such comparison impossible. However, the results can be placed in perspective.

The results for Argentina are lower than those of previous studies that considered more activities [29], but the rates of help needed to perform ADLs were quite low regardless. In Brazil, most previous estimates examined the population aged 60 or over [27,39], and the rates calculated in the most recent works are closer to the rates in the current study [40].

Chile uses the least comparable methodology in the region. It applies an algorithm to different sources that allows different options for statuses, activities, and intensity. The estimates are therefore heterogeneous and cannot be compared with other countries $[24,25,41,42]$. This may explain why the results of the current research differ from those of most such studies, with values that are lower than the ones previously calculated.

On the other hand, the results of this study are consistent with estimates made for Colombia, although slightly lower because the government's estimate considers a larger number of activities [43]. Most previous estimates for Mexico were based on an earlier source than the one used in this study and included more activities [44-48]; our results are therefore still high, though somewhat lower than in previous works. Uruguay is the only country with an existing LTC system, although its coverage is very limited. Nevertheless, its rates are the lowest, confirming the results of previous studies $[17,18,49]$.

This research shows that the percentages of people aged 65 and more needing help to carry out ADLs in Latin America are higher than in high-income countries in Europe or Asia [13,35]. The calculations made for this study, in addition to shedding light on the social, economic, and political challenges associated with demographic change [39], reveal the regional demand for help and indicate the magnitude of the task involved in developing an LTC system [50].

The limitations of this study are related to the sources and the selection of activities. The microdata were drawn from national surveys that implemented different sampling methodologies, with both the language and wording of the questionnaires differing between countries. Despite these issues, this is the first time the LTC demands of older adults in Latin American countries have been compared, and the availability of sources for longitudinal information would help to confirm or reject the evidence presented in this study.

\section{Conclusions}

This research evaluates the percentages of older adults who need help in the performance of ADLs in six Latin American countries that account for $70 \%$ of the regional economy. The work undertakes a cross-national analysis for the first time, and the results obtained have not been published before.

The main important outcome is of methodological nature. The study proposes indexes based on other indicators that are commonly used in the field worldwide (Katz index and Lawton scale). The surveys conducted were different for each country, but the meaning of the questions was similar, and a methodological discussion is thus started regarding the possibilities for using our method to analyze other national measures.

The second important outcome relates to the results by country. The upper limits of the ranges in both indexes are almost double the lower limits, meaning that the differences between countries are significant. The highest values are found in Brazil, followed by Colombia, with Argentina and Uruguay having the lowest values. Standardization by sex and age shows that, at the same age and for the same sex, there are still important differences between countries. It will be interesting to further study the determinants of these results. 
Complementary analyses also show consistency of results in terms of associations (correlation), representativeness of the activities (saturation), and concentration (distributions by number of ADL help).

The results have policy implications for the design and planning of national LTC systems. The region is in the process of discussing and implementing such services and requires evidence-based information on these issues, and the first step in the process consists of calculating the number of people who need help in performing ADLs $[3,10]$. Uruguay established its LTC system in 2015 [8,28], Costa Rica approved the development of its own system only in 2021 [9], and other countries are advancing in their national plans [26,27]. If the percentage of older adults needing help to perform ADLs is known and can be compared with other countries, the approximate size of the demand for care services can be calculated. This information will be useful for measuring the gap between supply and demand, and when combined with an estimate of the cost of the services, the economic resources required to implement these policies can be estimated. In addition, the disaggregation by sex and age allows the projection of future scenarios according to the demographic evolution of each country.

In summary, this study provides an international perspective of six Latin American countries. The high rates for all six are a cause for concern, and the implications of these findings are key to the development of LTC policies in the region, particularly for the purposes of determining demand, estimating the costs of policies, and planning the implementation of LTC systems.

Author Contributions: Conceptualization and methodology, M.M.-L.; formal analysis, investigation, resources, data curation, writing-original draft preparation, M.M.-L. and A.C.-C. All authors have read and agreed to the published version of the manuscript.

Funding: This research received no external funding.

Institutional Review Board Statement: Not applicable.

Informed Consent Statement: Not applicable.

Data Availability Statement: Original data can be requested or downloaded from: http:/ /datar. info/dataset/encaviam-2012 (ENCAVIAM 2012); http://elsi.cpqrr.fiocruz.br/ (ELSI 2015/16);

http:/ / observatorio.ministeriodesarrollosocial.gob.cl/encuesta-casen-2017 (CASEN 2017); https: //www.minsalud.gov.co/salud/publica/epidemiologia/Paginas/Estudios-y-encuestas.aspx (SABE 2015); https:/ /inegi.org.mx/programas/enasem/2018/?ps=microdatos (ENASEM 2018); https:/ / www.elps.org.uy/ (ELPS 2015/6) (accessed on 20 July 2021).

Acknowledgments: A.C.-C. is supported by a fellowship granted by the Organization of IberoAmerican States for Education, Science and Culture. The authors thank the National Institute of Statistics and Censuses of Argentina, Fundação Oswaldo Cruz do Brasil, Ministry of Social Development of Chile, Ministry of Health and Social Protection of Colombia, National Institute of Statistics and Censuses of Mexico, and Social Security Bank of Uruguay for the provision of the databases. All the results of the study are the responsibility of the author and do not represent these institutions.

Conflicts of Interest: The authors declare no conflict of interest. 


\section{Appendix A}

Table A1. BADL, IADL, and need of help. Original questions by survey (original languages).

\begin{tabular}{|c|c|c|c|}
\hline Country (Survey) & Question (Original) & Activities & Answer \\
\hline $\begin{array}{c}\text { Argentina } \\
\text { (ENCAVIAM) } \\
\text { Methodological documents: } \\
\text { https://bit.ly/36vPyJb }\end{array}$ & $\begin{array}{l}\text { Le voy a mencionar algunas } \\
\text { actividades para las que puede o } \\
\text { no necesitar ayuda de otras } \\
\text { personas. quisiera que me diga si } \\
\text { necesita ayuda para realizar cada } \\
\text { una de ellas. No tome en cuenta las } \\
\text { limitaciones transitorias, que } \\
\text { duren menos de tres meses. } \\
\text { ¿Necesita ayuda de una persona } \\
\text { para... }\end{array}$ & $\begin{array}{c}\text { Comer en un tiempo razonable (cortar la comida, llenar los vasos, etc.) }{ }^{4} \\
\text { Vestirse o desvestirse, incluyendo atarse los cordones }{ }^{1} \\
\text { Bañarse, incluyendo entrar y salir de la ducha o bañera } \\
\text { Peinarse, lavarse los dientes o lavarse la cara } \\
\text { Andar de un lado a otro de su casa } \\
\text { Usar el inodoro o higienizarse }{ }^{2} \\
\text { Acostarse o levantarse de la cama }{ }^{3} \\
\text { Andar de un lado a otro de su casa } \\
\text { Subir y bajar escaleras } \\
\text { Utilizar el teléfono, marcar los números y contestar una llamada } \\
\text { Viajar en transporte público, taxis, remis, auto particular, etc. } \\
\text { Organizar sus medicamentos y tomarlos }{ }^{7} \\
\text { Manejar su dinero }{ }^{8} \\
\text { Hacer las compras }{ }^{5} \\
\text { Preparar comidas calientes }{ }^{6} \\
\text { Hacer las tareas del hogar (lavar platos, tender camas, barrer, etc.) }\end{array}$ & $\begin{array}{c}\text { 1. Si } \\
\text { 2. No } \\
\text { Reclassification in HELP (dichotomous } \\
\text { variable): } \\
\text { No: No } \\
\text { Yes: } \mathrm{Si}\end{array}$ \\
\hline $\begin{array}{c}\text { Brazil } \\
\text { (ELSI) } \\
\text { Methodological documents: } \\
\text { https://bit.ly /3k54Ix0 }\end{array}$ & $\begin{array}{l}\text { Agora farei algumas perguntas } \\
\text { sobre atividades que algumas } \\
\text { pessoas têm dificuldades para } \\
\text { realizar, devido a problemas de } \\
\text { saúde, incluindo sua memória. } \\
\text { Peço que não considere } \\
\text { dificuldades temporárias, aquelas } \\
\text { que o(a) Sr.(a) espera que durem } \\
\text { menos de três meses. } \\
\text { O(A) Sr.(a) recebe ajuda para }\end{array}$ & $\begin{array}{c}\text { Fazer sua higiene pessoal } \\
\text { Preparar uma refeição quente }{ }^{6} \\
\text { Administrar o próprio dinheiro } 8 \\
\text { Utilizar algum tipo de transporte } \\
\text { Fazer compras }{ }^{5} \\
\text { Utilizar o telefone } \\
\text { Administrar os próprios medicamentos }{ }^{7} \\
\text { Realizar tarefas domésticas leves (arrumar cama, tirar pó', } \\
\text { cuidar do lixo etc.) } \\
\text { Realizar tarefas domésticas pesadas (lavar banheiro, limpar quintal, etc.) } \\
\text { Caminhar um cômodo ou andar de um cômodo para outro } \\
\text { no mesmo andar } \\
\text { Vestirse }{ }^{1} \\
\text { Tomar banho } \\
\text { Comer }{ }^{4} \\
\text { Citar-se/ou levantar da cama }{ }^{3} \\
\text { Usar o banheiro }{ }^{2}\end{array}$ & $\begin{array}{c}\text { 1. Não, porque não precisa } \\
\text { 2. Não, porque não ajuda } \\
\text { 3. Sim } \\
\text { Reclassification in HELP } \\
\text { (dichotomous variable): } \\
\text { No: Não, porque não precisa } \\
\text { Yes: Sim; Não, porque não ajuda }\end{array}$ \\
\hline
\end{tabular}


Table A1. Cont.

\begin{tabular}{|c|c|c|c|}
\hline Country (Survey) & Question (Original) & Activities & Answer \\
\hline $\begin{array}{c}\text { Chile } \\
\text { (CASEN) } \\
\text { Methodological documents: } \\
\text { https:/ / bit.ly/3yZNkOL }\end{array}$ & $\begin{array}{l}\text { Considerando sólo su estado de } \\
\text { salud, ¿con qué frecuencia recibe } \\
\text { ayuda de otra persona para: }\end{array}$ & $\begin{array}{c}\text { Comer (incluyendo cortar comida y llenar los vasos) } \\
\text { Bañarse (incluyendo entrar y salir de la tina) } \\
\text { Moverse / desplazarse dentro de la casa } \\
\text { Utilizar el W.C. o retrete }{ }^{2} \\
\text { Acostarse y levantarse de la cama }{ }^{3} \\
\text { Vestirse }{ }^{1} \\
\text { Salir a la calle } \\
\text { Hacer compras o ir al médico } \\
\text { Realizar sus tareas del hogar } \\
\text { Hacer o recibir llamadas }\end{array}$ & $\begin{array}{c}\text { 1. Nunca; } \\
\text { 2. Casi nunca; } \\
\text { 3. Algunas veces; } \\
\text { 4. Muchas veces; } \\
\text { 5. Siempre. } \\
\text { Reclassification in HELP } \\
\text { (dichotomous variable): } \\
\text { No: Nunca } \\
\text { Yes: Casi nunca; Algunas veces; Muchas } \\
\text { veces; Siempre }\end{array}$ \\
\hline \multirow{5}{*}{$\begin{array}{c}\text { Colombia } \\
\text { (SABE) } \\
\text { Methodological documents: } \\
\text { https:/ / bit.ly /36wAFX4 }\end{array}$} & \multirow{5}{*}{$\begin{array}{c}\text { Vamos a hablar de las actividades } \\
\text { básicas de la vida diaria (BADL) } \\
\text { que una persona puede realizar de } \\
\text { forma independiente o } \\
\text { dependiente. En cuanto a } \\
\text { [actividad] Ud. fue capaz de ... }\end{array}$} & Alimentación 4 & $\begin{array}{l}\text { 1. Comer por usted mismo, } \\
\text { comer Independiente } \\
\text { 2. Necesitó ayuda de otra persona } \\
\text { 3. Necesitó ser alimentado por otra persona }\end{array}$ \\
\hline & & Baño & $\begin{array}{l}\text { 1. Bañarse solo } \\
\text { 2. Necesitó ayuda de otra persona } \\
\text { para bañarse }\end{array}$ \\
\hline & & Arreglarse & $\begin{array}{l}\text { 1. Arreglarse sin ninguna ayuda } \\
\text { 2. Necesita de la ayuda de otra persona }\end{array}$ \\
\hline & & Deposición & $\begin{array}{l}\text { 1. No tuvo accidentes (es continente) } \\
\text { 2. Ha tenido accidentes ocasionales } \\
\text { 3. No es capaz de retener (Incontinente) }\end{array}$ \\
\hline & & Micción & $\begin{array}{l}\text { 1. No tuvo accidentes (es continente) } \\
\text { 2. Ha tenido accidentes ocasionales } \\
\text { 3. No es capaz de retener (Incontinente) }\end{array}$ \\
\hline
\end{tabular}


Table A1. Cont.

\begin{tabular}{|c|c|c|c|}
\hline Country (Survey) & Question (Original) & Activities & Answer \\
\hline \multirow{4}{*}{$\begin{array}{c}\text { Colombia } \\
\text { (SABE) } \\
\text { Methodological documents: } \\
\text { https:/ / bit.ly / 36wAFX4 }\end{array}$} & \multirow{4}{*}{$\begin{array}{l}\text { Vamos a hablar de las actividades } \\
\text { básicas de la vida diaria (BADL) } \\
\text { que una persona puede realizar de } \\
\text { forma independiente o } \\
\text { dependiente. En cuanto a } \\
\text { [actividad] Ud. fue capaz de ... }\end{array}$} & Uso del inodoro o sanitario ${ }^{2}$ & $\begin{array}{l}\text { 1. Ir solo al sanitario y utilizarlo } \\
\text { 2. Necesitó algún tipo de ayuda cuando } \\
\text { usó el sanitario } \\
\text { 3. Requiere ayuda total cuando } \\
\text { entra al sanitario }\end{array}$ \\
\hline & & Traslado cama-silla ${ }^{3}$ & $\begin{array}{l}\text { 1. Es capaz de pasarse solo de la cama } \\
\text { a una silla } \\
\text { 2. Necesita algún tipo de ayuda para } \\
\text { pasarse de la cama a silla } \\
\text { 3. No puede solo, necesita ayuda de } \\
\text { otra persona } \\
\text { 4. No es capaz de pasarse y necesita que } \\
\text { lo carguen }\end{array}$ \\
\hline & & Deambulación & $\begin{array}{l}\text { 1. Camina solo sin problemas } \\
\text { (Independiente) } \\
\text { 2. Necesita algún tipo de ayuda } \\
\text { para caminar } \\
\text { 3. Está en silla de ruedas } \\
\text { 4. No puede caminar (Inmóvil) }\end{array}$ \\
\hline & & Subir y bajar escalones & $\begin{array}{l}\text { 1. Es capaz de subir y bajar escaleras solo } \\
\text { 2. Necesita ayuda para subir y } \\
\text { bajar escaleras } \\
\text { 3. No es capaz de subir ni bajar escaleras } \\
\text { Reclassification in HELP } \\
\text { (dichotomous variable): } \\
\text { No: Camina solo sin problemas; Ir solo al } \\
\text { sanitario y utilizarlo; Comer por usted } \\
\text { mismo; Es capaz de pasarse solo de la cama } \\
\text { a una silla; Vestirse solo usted mismo } \\
\text { Yes: Resto de opciones }\end{array}$ \\
\hline
\end{tabular}


Table A1. Cont.

\begin{tabular}{|c|c|c|c|}
\hline Country (Survey) & Question (Original) & Activities & Answer \\
\hline $\begin{array}{c}\text { Colombia } \\
\text { (SABE) } \\
\text { Methodological documents: } \\
\text { https:/ / bit.ly/36wAFX4 }\end{array}$ & $\begin{array}{l}\text { Le mencionaré algunas actividades } \\
\text { de la vida diaria, por favor } \\
\text { responda teniendo en cuenta la } \\
\text { que se ajuste a sus condiciones } \\
\text { actuales. ¿Puede usted realizar las } \\
\text { siguientes actividades? Es capaz }\end{array}$ & $\begin{array}{c}\text { Maneja su propio dinero }{ }^{8} \\
\text { Es capaz de hacer las compras del diario (esp. comida) }{ }^{5} \\
\text { Es capaz de preparar la comida }{ }^{6} \\
\text { Es capaz de manejar sus propios medicamentos }{ }^{7} \\
\text { Uso de trasporte publico o taxi } \\
\text { Uso de teléfono }\end{array}$ & $\begin{array}{l}\text { 1. Lo hace sin ayuda de nadie y sin } \\
\text { dificultad } \\
\text { 2. Lo hace sin ayuda, pero con dificultad } \\
\text { 3. Necesita (o necesitaría) ayuda para } \\
\text { hacerlo } \\
\text { 4. No es capaz de hacerlo } \\
\text { Reclassification in HELP (dichotomous } \\
\text { variable): } \\
\text { No: Lo hace sin ayuda de nadie y sin } \\
\text { dificultad } \\
\text { Yes: Lo hace sin ayuda, pero con dificultad; } \\
\text { Necesita (o necesitaría) ayuda para hacerlo; } \\
\text { No es capaz de hacerlo. }\end{array}$ \\
\hline $\begin{array}{c}\text { Mexico } \\
\text { (ENASEM) } \\
\text { Methodological documents: } \\
\text { https:/ / bit.ly /36tZq6m }\end{array}$ & $\begin{array}{l}\text { Por favor dígame si tiene alguna } \\
\text { dificultad con cada una de las } \\
\text { actividades que le voy a mencionar. } \\
\text { Si usted no hace ninguna de las } \\
\text { siguientes actividades, } \\
\text { simplemente dígamelo. No incluya } \\
\text { dificultades que cree que durarán } \\
\text { menos de tres meses. (A quienes } \\
\text { responden afirmativamente alguna } \\
\text { de estas actividades, se le pregunta } \\
\text { si recibe ayuda de alguien) }\end{array}$ & $\begin{array}{c}\text { Vestirse, incluyendo ponerse los zapatos y los calcetines }{ }^{1} \\
\text { Caminar de un lado a otro de un cuarto } \\
\text { Comer, por ejemplo, para cortar su comida } \\
\text { Acostarse y levantarse de la cama }{ }^{3} \\
\text { Usar el excusado, incluyendo subirse y bajarse o ponerse en cuclillas }{ }^{2} \\
\text { Preparar una comida caliente }{ }^{6} \\
\text { Hacer compras de víveres } / \text { mandado }^{5} \\
\text { Tomar medicamentos (si toma alguno o tuviera que tomar alguno) }{ }^{7} \\
\text { Manejar su dinero }{ }^{8}\end{array}$ & $\begin{array}{c}\text { 1. Si } \\
\text { 2. No } \\
\text { Reclassification in HELP (dichotomous } \\
\text { variable): } \\
\text { No: No } \\
\text { Yes: } \mathrm{Si}\end{array}$ \\
\hline
\end{tabular}


Table A1. Cont.

\begin{tabular}{|c|c|c|c|}
\hline Country (Survey) & Question (Original) & Activities & Answer \\
\hline $\begin{array}{c}\text { Uruguay } \\
\text { (ELPS) } \\
\text { Methodological documents: } \\
\text { https:/ / bit.ly / 2TZ43CL }\end{array}$ & $\begin{array}{c}\text { ¿Necesita ayuda de otras personas } \\
\text { para realizar alguna de estas } \\
\text { actividades? }\end{array}$ & $\begin{array}{c}\text { Ir al baño (Incluye ubicación, manipular ropa, adoptar } \\
\text { postura y limpiarse) }{ }^{2} \\
\text { Peinarse, cortarse las uñas, lavarse el pelo o los dientes } \\
\text { Comer o beber }{ }^{4} \\
\text { Vestirse }^{1} \\
\text { Evitar riesgos de salud, pedir ayuda o seguir tratamiento } \\
\text { Cambiar y mantener la posición }{ }^{3} \\
\text { Desplazarse dentro del hogar } \\
\text { Desplazarse fuera del hogar } \\
\text { Realizar tareas domésticas (cocinar, hacer compras, limpiar) } \\
\text { Participar en la vida social y comunitaria } \\
\text { Comunicarse y tomar decisiones }\end{array}$ & $\begin{array}{c}\text { 1. No requiere } \\
\text { 2. Casi nunca } \\
\text { 3. Algunas veces } \\
\text { 4. Muchas veces } \\
\text { 5. Siempre } \\
\text { Reclassification in HELP } \\
\text { (dichotomous variable): } \\
\text { No: No requiere } \\
\text { Yes: Casi nunca; Algunas veces; Muchas } \\
\text { veces; Siempre }\end{array}$ \\
\hline
\end{tabular}

Table A2. BADL, IADL and need of help. Original questions by survey (in English).

Country (Survey)

I'm going to mention a few activities for which you may or may not need Argentina (ENCAVIAM)

Methodological documents: https: / / bit.ly/36vPyJb

you to tell me if you need help in

carrying out each of them. Do not take

into account transitional limitations,
Question (Original)

\section{Activities}

Answer

Eating in a reasonable time (cutting food, filling glasses, etc.) ${ }^{4}$ Dressing or undressing, including tying laces ${ }^{1}$

Bathing, including getting in and out of the shower or bathtub Combing, brushing your teeth, or washing your face
Walking around your house
Using the toilet or sanitizing ${ }^{2}$
Lying down or getting out of bed ${ }^{3}$
1. Yes
2. No

Walking around your house

which last less than three months.

Need help from a person to...
Use the phone, dial numbers and answer a call

Travel by public transport, taxis, remis, private car, etc.

Organize your medications and take them ${ }^{7}$

$$
\begin{gathered}
\text { Managing your money } \\
\text { Shopping }
\end{gathered}
$$

Prepare hot meals 6

Doing household work (washing dishes, laying beds, sweeping, etc.)
Reclassification in HELP

(dichotomous variable):

No: No

Yes: Yes 
Table A2. Cont.

\begin{tabular}{|c|c|c|c|}
\hline Country (Survey) & Question (Original) & Activities & Answer \\
\hline $\begin{array}{c}\text { Brazil } \\
\text { (ELSI) } \\
\text { Methodological documents: } \\
\text { https://bit.ly/3k54Ix0 }\end{array}$ & $\begin{array}{l}\text { Now I'm going to ask you some } \\
\text { questions about activities that some } \\
\text { people have difficulty performing due } \\
\text { to health problems, including } \\
\text { their memory. } \\
\text { I ask you not to consider temporary } \\
\text { difficulties, those that you expect to } \\
\text { last less than three months. } \\
\text { You receive help to }\end{array}$ & $\begin{array}{c}\text { Do your personal hygiene } \\
\text { Preparing a hot meal }{ }^{6} \\
\text { Managing your money }^{8} \\
\text { Use some kind of transport } \\
\text { Shopping }{ }^{5} \\
\text { Using your phone } \\
\text { Administering your own medicines }{ }^{7} \\
\text { Perform light household work (make up bed, dust, take care of } \\
\text { garbage, etc.) } \\
\text { Perform heavy household work (bathroom wash, clean yard, etc.) } \\
\text { Walk one room or walk from one room to another on the same floor } \\
\text { Dressing }{ }^{1} \\
\text { Showering } \\
\text { Eating }{ }^{4} \\
\text { Lie down/or get out of bed }{ }^{3} \\
\text { Using the bathroom }{ }^{2}\end{array}$ & $\begin{array}{l}\text { 1. No, because you don't need } \\
\text { 2. No, because it doesn't help } \\
\text { 3. Yes } \\
\text { Reclassification in HELP } \\
\text { (dichotomous variable): } \\
\text { No: No, because you don't need } \\
\text { Yes: Yes; No, because it doesn't help }\end{array}$ \\
\hline $\begin{array}{c}\text { Chile } \\
\text { (CASEN) } \\
\text { Methodological documents: } \\
\text { https:/ / bit.ly/3yZNkOL }\end{array}$ & $\begin{array}{l}\text { Considering only your state of health, } \\
\text { how often do you get help from } \\
\text { someone else to: }\end{array}$ & $\begin{array}{c}\text { Eating (including cutting food and filling glasses) } \\
\text { Bathing (including entering and exiting the tub) } \\
\text { Move/move inside the house } \\
\text { Use the W.C. or toilet }{ }^{2} \\
\text { Lying down and getting out of bed }{ }^{3} \\
\text { Dressing }{ }^{1} \\
\text { Going out on the street } \\
\text { Shopping or going to the doctor } \\
\text { Perform your household chores } \\
\text { Make or receive calls }\end{array}$ & $\begin{array}{l}\text { 1. Never; } \\
\text { 2. Almost never; } \\
\text { 3. Sometimes; } \\
\text { 4. Many times; } \\
\text { 5. Always. } \\
\text { Reclassification in HELP } \\
\text { (dichotomous variable): } \\
\text { No: Never } \\
\text { Yes: Almost never; Sometimes; Many } \\
\text { times; always }\end{array}$ \\
\hline
\end{tabular}


Table A2. Cont.

\begin{tabular}{|c|c|c|c|}
\hline Country (Survey) & Question (Original) & Activities & Answer \\
\hline \multirow{8}{*}{$\begin{array}{c}\text { Colombia } \\
\text { (SABE) } \\
\text { Methodological documents: } \\
\text { https:/ / bit.ly /36wAFX4 }\end{array}$} & \multirow{8}{*}{$\begin{array}{l}\text { Let's talk about the basic activities of } \\
\text { daily living (BADL) that a person can } \\
\text { perform independently or } \\
\text { dependently. As for [activity] You } \\
\text { were able to... }\end{array}$} & Eating ${ }^{4}$ & $\begin{array}{l}\text { 1. Eat for yourself, eat Independent } \\
\text { 2. Needed help from someone else } \\
\text { 3. Needed to be fed by someone else }\end{array}$ \\
\hline & & Bathing & $\begin{array}{l}\text { 1. Bathing alone } \\
\text { 2. He needed help from someone else } \\
\text { to bathe }\end{array}$ \\
\hline & & Dressing $^{1}$ & $\begin{array}{l}\text { 1. Dress up only yourself } \\
\text { 2. He needed someone to help him } \\
\text { 3. They have to dress it }\end{array}$ \\
\hline & & Grooming & $\begin{array}{l}\text { 1. Fix yourself without any help } \\
2 \text {. Need someone else's help }\end{array}$ \\
\hline & & Deposition & $\begin{array}{l}\text { 1. Had no accidents (it's continent) } \\
\text { 2. Have had occasional accidents } \\
\text { 3. Not able to retain (Incontinent) }\end{array}$ \\
\hline & & Urination & $\begin{array}{l}\text { 1. Had no accidents (it's continent) } \\
\text { 2. Have had occasional accidents } \\
\text { 3. Not able to retain (Incontinent) }\end{array}$ \\
\hline & & Use of the toilet ${ }^{2}$ & $\begin{array}{l}\text { 1. Go alone to the toilet and use it } \\
\text { 2. He needed some help when he used } \\
\text { the toilet } \\
\text { 3. Requires full help when you enter } \\
\text { the toilet }\end{array}$ \\
\hline & & Transfer bed-chair ${ }^{3}$ & $\begin{array}{l}\text { 1. You are able to go alone from the bed } \\
\text { to a chair } \\
\text { 2. You need some help to move from } \\
\text { bed to chair } \\
\text { 3. You can't alone, you need help from } \\
\text { someone else } \\
\text { 4. It is not able to pass and needs } \\
\text { to be loaded }\end{array}$ \\
\hline
\end{tabular}


Table A2. Cont.

Country (Survey)
Question (Original)
Activities

Walking

\section{Answer}

1. Walk alone without problems (Independent)

2. You need some kind of walking help

3. You are in a wheelchair

4. Can't walk (Motionless)

Let's talk about the basic activities of daily living (BADL) that a person can perform independently or

dependently. As for [activity] You

Colombia

(SABE)

Methodological documents:

https:/ / bit.ly/36wAFX4
Up and down steps

$$
\text { were able to... }
$$

I will mention some activities of daily living, please respond taking into account the one that fits your current conditions. Can you do the following activities? It is capable
Manage your own money ${ }^{8}$ It is able to do the daily shopping (esp. food $)^{5}$ It is able to prepare food ${ }^{6}$

You are able to manage your own medications ${ }^{7}$ Use of public transport or taxi Phone usage
1. You are able to go up and down stairs alone

2. Need help going up and down stairs

3. Not able to go up or down stairs

Reclassification in HELP

(dichotomous variable):

No: Walk alone without problems; Go

alone to the toilet and use it; Eat for

yourself; $\mathrm{He}$ is able to go alone from the

bed to a chair; Dress up only yourself Yes: Other options

1. It does it without help from anyone and without difficulty

2. It does it without help, but with difficulty

3. You need (or would need) help doing so

4. You're not able to do it

Reclassification in HELP

(dichotomous variable):

No: It does it without help from anyone and without difficulty

Yes: He does it without help, but with

difficulty; You need (or would need) help

doing so; It is not capable of doing so. 
Table A2. Cont.

\begin{tabular}{|c|c|c|c|}
\hline Country (Survey) & Question (Original) & Activities & Answer \\
\hline $\begin{array}{c}\text { Mexico } \\
\text { (ENASEM) } \\
\text { Methodological documents: } \\
\text { https://bit.ly/36tZq6m }\end{array}$ & $\begin{array}{l}\text { Please tell me if you have any difficulty } \\
\text { with each of the activities I am going } \\
\text { to mention. If you don't do any of the } \\
\text { following activities, just tell me. Don't } \\
\text { include difficulties that you think will } \\
\text { last less than three months. (Those } \\
\text { who answer in the affirmative are } \\
\text { asked if they get help from anyone.) }\end{array}$ & $\begin{array}{c}\text { Dressing, including putting on shoes and socks }{ }^{1} \\
\text { Walking back and forth in a room } \\
\text { Eating, for example, to cut your food }{ }^{4} \\
\text { Lying down and getting out of bed }{ }^{3} \\
\text { Use the toilet, including getting on and off or squatting }{ }^{2} \\
\text { Prepare a hot meal }{ }^{6} \\
\text { Shopping for groceries }{ }^{5} \\
\text { Taking medicines (if you take any or need to take one })^{7} \\
\text { Managing your money }{ }^{8}\end{array}$ & $\begin{array}{c}\text { 1. Yes } \\
\text { 2. No } \\
\text { Reclassification in HELP (dichotomous } \\
\text { variable): } \\
\text { No: No } \\
\text { Yes: Yes }\end{array}$ \\
\hline $\begin{array}{c}\text { Uruguay } \\
\text { (ELPS) } \\
\text { Methodological documents: } \\
\text { https:/ / bit.ly / 2TZ43CL }\end{array}$ & $\begin{array}{c}\text { Do you need help from other people to } \\
\text { do any of these activities? }\end{array}$ & $\begin{array}{c}\text { Go to the bathroom (Includes location, handling clothes, posture and } \\
\text { cleaning) }{ }^{2} \\
\text { Combing, cutting nails, washing your hair or teeth } \\
\text { Eating or drinking }{ }^{4} \\
\text { Dressing }{ }^{1} \\
\text { Avoid health risks, ask for help or follow treatment } \\
\text { Change and maintain position }{ }^{3} \\
\text { Moving within the home } \\
\text { Moving outside the home } \\
\text { Perform household chores (cooking, shopping, cleaning) } \\
\text { Participate in social and community life } \\
\text { Communicating and making decisions }\end{array}$ & $\begin{array}{l}\text { 1. Not required } \\
\text { 2. Almost never } \\
\text { 3. Sometimes } \\
\text { 4. Many times } \\
\text { 5. Always } \\
\text { Reclassification in HELP (dichotomous } \\
\text { variable): } \\
\text { No: Not required } \\
\text { Yes: Almost never; Sometimes; Many } \\
\text { times; always }\end{array}$ \\
\hline
\end{tabular}

1,2,3,4 Activities for BADL index; ${ }^{5,6,7,8}$ Activities for IADL index. 


\section{References}

1. United Nations. Revision of World Population Prospects 2019. Available online: https://population.un.org/wpp (accessed on 4 March 2021).

2. Grané, A.; Albarrán, I.; Merchán, D.E. Impact of pandemic on European Well-Being: Visualizing Scenarios from the SHARE Database. Int. J. Environ. Res. Public Health 2021, 18, 4620. [CrossRef] [PubMed]

3. World Health Organization. Global Strategy and Action Plan on Ageing and Health; World Health Organization: Geneva, Switzerland, 2017.

4. Economic Commission for Latin America and the Caribbean. The Inefficiency of Inequality; Economic Commission for Latin America and the Caribbean: Santiago, Chile, 2018.

5. World Health Organization. A Glossary of Terms for Community Health Care and Services for Older Persons; Aging and Health Technical Report 5; World Health Organization: Kobe City, Japan, 2004.

6. Organization for Economic Cooperation and Development. Health at a Glance 2019; Organization for Economic Cooperation and Development: Paris, France, 2019. [CrossRef]

7. Matus-López, M. Thinking about long-term care policies for Latin America. Salud Colect. 2015, 11, 485-496. [CrossRef] [PubMed]

8. Matus-Lopez, M.; Terra, F. The Long-Term Care System in Uruguay. Soc. Policy Ctry. Briefs 2021, 1342. [CrossRef]

9. Matus-Lopez, M.; Chaverri, A. Progress toward long-term care protection in Latin America. A national long-term care system in Costa Rica. Jamda 2021. [CrossRef]

10. Medellín, N.; Ibarrarán, P.; Stampini, M.; Matus-López, M. Cuatro Elementos Para Diseñar un Sistema de Cuidados; Nota Técnica IDB-TN 1438; Inter-American Development Bank: Washington, DC, USA, 2018. [CrossRef]

11. Spector, W.D.; Fleishman, J.A. Combining activities of daily living with instrumental activities of daily living to measure functional disability. J. Gerontol. B Psychol. Sci. Soc. Sci. 1998, 53, S46-S57. [CrossRef] [PubMed]

12. Roe, B.; Whattam, M.; Young, H.; Dimond, M. Elders' needs and experiences of receiving formal and informal care for their activities of daily living. J. Clin. Nurs. 2001, 10, 389-397. [CrossRef]

13. LaPlante, M.P. The classic measure of disability in activities of daily living is biased by age but an expanded IADL/ADL measure is not. J. Gerontol. B Psychol. Sci. Soc. Sci. 2010, 65, 720-732. [CrossRef]

14. Albarrán Lozano, I.; Alonso González, P.; Bolancé Losillas, C. Comparación de los baremos español, francés y alemán para medir la dependencia de las personas con discapacidad y sus prestaciones. Rev. Esp. Salud Publica 2009, 83, 379-392. [CrossRef]

15. Rodríguez, P. Atención a las Personas en Situación de Dependencia en España. Libro Blanco; Ministerio de Trabajo y Asuntos Sociales: Madrid, Spain, 2005.

16. Colin, C. Le nombre de personnes âgées dépendantes d'après l'enquête Handicaps-incapacités-dépendance. Etudes Result. 2000, 94, 1-8.

17. Pugliese, L.; Sosa, S. Adultos mayores dependientes. Insumos de la ELPS para el Sistema Nacional de Cuidados. Coment Segur. Soc. 2015, 48, 61-80.

18. Batthyány, K.; Berriel, F.; Carbajal, M.; Genta, N.; Paredes, M.; Pérez Fernández, R.; Perrotta, V. Las Personas Mayores Ante el Cuidado. Aportes de Inmayores para la Construcción de un Sistema Nacional de Cuidados; Ministerio de Desarrollo Social: Montevideo, Uruguay, 2014.

19. Fillenbaum, G.G.; Blay, S.L.; Andreoli, S.B.; Gastal, F.L. Prevalence and correlates of functional status in an older communityrepresentative sample in Brazil. J. Aging Health 2010, 22, 362-383. [CrossRef]

20. Jotheeswaran, A.T.; Bryce, R.; Prina, M.; Acosta, D.; Ferry, C.P.; Guerra, M.; Huang, Y.; Llibre Rodríguez, J.J.; Salas, A.; Sosa, A.L.; et al. Frailty and the prediction of dependence and mortality in low-and middle-income countries: A 10/66 populationbased cohort study. BMC Med. 2015, 13, 138. [CrossRef]

21. Prina, A.M.; Wu, Y.T.; Kralj, C.; Acosta, D.; Acosta, A.; Guerra, M.; Huang, Y.; Jotheeswaran, A.T.; Jiménez-Velasquez, I.Z.; Liu, Z.; et al. Dependence-and disability-free life expectancy across eight low-and middle-income countries: A 10/66 study. J. Aging Health 2019, 32, 401-409. [CrossRef]

22. Palloni, A.; McEniry, M.; Wong, R.; Peláez, M. The tide to come: Elderly health in Latin America and the Caribbean. J. Aging Health 2006, 18, 180-206. [CrossRef] [PubMed]

23. Llibre Rodríguez, J.J.; Prina, A.M.; Acosta, D.; Guerra, M.; Huanq, Y.; Jacob, K.S.; Jiménez-Velasquez, I.Z.; Salas, A.; Sosa, A.L.; Williams, J.D.; et al. The prevalence and correlates of frailty in urban and rural populations in Latin America, China, and India: A 10/66 population-based survey. J. Am. Med. Dir. Assoc. 2018, 19, 287-295.e4. [CrossRef] [PubMed]

24. Arce, P.; Cerón, G.; González, F.; Guerrero, M.; Pinto, S. Caracterización de la Dependencia en las Personas en Situación de Discapacidad a Partir del II Estudio Nacional de la Discapacidad; SENADIS: Santiago, Chile, 2017.

25. González, F.; Massad, C.; Lavanderos, F. Estudio Nacional de la Dependencia en las Personas Mayores; SENAMA: Santiago, Chile, 2010. [CrossRef]

26. Matus-López, M.; Cid, C. Building long-term care policies in Latin America: New programs in Chile. J. Am. Med. Dir. Assoc. 2015, 16, 900.e7-900.e10. [CrossRef]

27. Gragnolati, M.; Jorgensen, O.H.; Rocha, R.; Fruttero, A. Health care and long-term care. In Growing Old in an Older Brazil; Gragnolati, M., Jorgensen, O.H., Rocha, R., Fruttero, A., Eds.; The World Bank: Washington, DC, USA, 2011; Volume 1, pp. 121-165. [CrossRef] 
28. Matus-Lopez, M.; Cid, C. New long-term care policies in Latin America: The National System of Care in Uruguay. J. Am. Med. Dir. Assoc. 2016, 17, 663-665. [CrossRef] [PubMed]

29. Monteverde, M.; Tomas, S.; Acosta, L.; Garay, S. Envejecimiento poblacional y magnitud de la dependencia en Argentina y México: Perspectiva comparada con España. Rev. Latinoam. Población 2016, 18, 135-154. [CrossRef]

30. Katz, S.; Ford, A.B.; Moskowitz, R.W.; Jackson, B.A.; Jaffe, M.W. Studies of illness in the aged: The index of ADL: A standardized measure of biological and psychosocial function. J. Am. Med. Assoc. 1963, 185, 914-919. [CrossRef] [PubMed]

31. Lawton, M.P.; Brody, E.M. Assessment of older people: Self-maintaining and instrumental activities of daily living. Gerontologist 1969, 9, 179-186. [CrossRef]

32. Hopman-Rock, M.; Van Hirtum, H.; De Vreede, P.; Freiberger, E. Activities of daily living in older community-dwelling persons: A systematic review of psychometric properties of instruments. Aging Clin. Exp. Res. 2019, 31, 917-925. [CrossRef] [PubMed]

33. Ayala, A.; Pujol, R.; Forjaz, M.J.; Abellán, A. Comparación de métodos de escalamiento de actividades de la vida diaria en personas mayores. Gac. Sanit. 2019, 33, 511-516. [CrossRef] [PubMed]

34. Forjaz, M.J.; Ayala, A.; Abellán, A. Hierarchical nature of activities of daily living in the Spanish Disability Survey. Rheumatol. Int. 2015, 35, 1581-1589. [CrossRef] [PubMed]

35. Jang, S.N.; Kawachi, I. Why do older Korean adults respond differently to activities of daily living and instrumental activities of daily living? A differential item functioning analysis. Ann. Geriatr. Med. Res. 2019, 23, 197-203. [CrossRef]

36. Pashmdarfard, M.; Azad, A. Assessment tools to evaluate activities of daily living (ADL) and instrumental activities of daily living (IADL) in older adults: A systematic review. Med. J. Islam Repub. Iran 2020, 34, 33. [CrossRef] [PubMed]

37. Albarrán-Lozano, I.; Alonso-González, P.; Arribas-Gil, A. Dependence evolution in the Spanish disabled population: A functional data analysis approach. J. R. Stat Soc. Ser. A Stat. Soc. 2017, 180, 657-677. [CrossRef]

38. Albarrán-Lozano, I.; Alonso-González, P.; Arribas-Gil, A.; Grané, A. How functional data can enhance the estimation of health expectancy: The case of the disabled Spanish population. ASTIN Bull. J. Int. Actuar. Assoc. 2019, 49, 57-84. [CrossRef]

39. Andrade, T.B.; Andrade, F.B. Unmet need for assistance with activities of daily life among older adults in Brazil. Rev. Saude Publica 2018, 52, 75. [CrossRef]

40. Giacomin, K.C.; Duarte, Y.A.; Camarano, A.A.; Nunes, D.P.; Fernandes, D. Care and functional disabilities in daily activitiesELSI-Brazil. Rev. Saude Publica 2018, 52 (Suppl. 2), 9s. [CrossRef]

41. Villalobos, P. Panorama de la dependencia en Chile: Avances y desafíos. Rev. Med. Chil. 2019, 147, 83-90. [CrossRef]

42. Ministerio de Desarrollo Social. Adultos Mayores. Sintesis de Resultados. CASEN 2017; Ministerio de Desarrollo Social: Santiago, Chile, 2017.

43. Ministerio de Salud y Protección Social. SABE Colombia 2015: Estudio Nacional de Salud, Bienestar y Envejecimiento; MINSALUD: Bogotá, Colombia, 2016.

44. Dorantes-Mendoza, G.; Ávila-Fuñes, J.A.; Mejía-Arango, S.; Gutiérrez-Robledo, L.M. Factors associated with functional dependence in older adults: A secondary analysis of the National Study on Health and Aging, Mexico, 2001. Rev. Panam. Salud Publica 2007, 22, 1-11. [CrossRef] [PubMed]

45. Gallegos-Carrillo, K.; García-Peña, C.; Durán-Muñoz, C.; Reyes, H.; Durán-Arenas, L. Self-perceived health status: An approach of the elderly in Mexico. Rev. Saude Publica 2006, 40, 792-801. [CrossRef]

46. Barrantes-Monge, M.; García-Mayo, E.J.; Gutiérrez-Robledo, L.M.; Miguel-Jaimes, A. Dependencia funcional y enfermedades crónicas en ancianos mexicanos. Salud Publica Mex. 2007, 49, 459-466. [CrossRef]

47. Monteverde, M.; Noronha, K.; Palloni, A.; Angeletti, K. Costos individuales esperados de cuidados de larga duración en Buenos Aires, México y Puerto Rico. In Sociedad y Adulto Mayor en América Latina. Estudios Sobre Envejecimiento en la Región; Peláez, E., Ed.; Asociación Latinoamericana de Población: Córdoba, Argentina, 2008; Volume 1, pp. 139-160.

48. López-Ortega, M.; Aranco, N. Envejecimiento y Atención a la Dependencia en México; Nota Técnica IDB-TN 1614; Inter-American Development Bank: Washington, DC, USA, 2019. Available online: https://publications.iadb.org/publications/spanish/ document/Envejecimiento_y_atenci\%C3\%B3n_a_la_dependencia_en_M\%C3\%A9xico_es.pdf (accessed on 1 May 2021).

49. Marroig, A.; Machado, M.; Muniz-Terrera, G. Dependency change with aging and associated factors in Uruguay: A Cohort Study. J. Aging Health 2021, 0, 1-10. [CrossRef]

50. Laferrère, A.; Van den Bosch, K. Unmet need for long-term care and social exclusion. In Ageing in Europe-Supporting Policies for an Inclusive Society; Börsch-Supan, A., Kneip, T., Litwin, H., Myck, M., Weber, G., Eds.; De Gruyter: Berlin, Germany, 2015; Volume 1, pp. 331-342. [CrossRef] 